\title{
BASIS PROBLEMS UNDER SECTION 1014(b)(9) RESULTING FROM DEATH OF THE SETTLOR-REVERSIONER OF AN INTER VIVOS TRUST
}

Several troublesome basis problems are presented when a settlor gives property in trust to pay the income to a beneficiary for life or a term of years, ${ }^{1}$ retaining the reversion, and thereafter predeceases the beneficiary at a time when the value of his reversion is different from its basis, the reversion then passing to his legatee. There are three familiar interests for which basis decisions must be made: the reversion, life estate, and trust corpus. ${ }^{2}$ The problem is to ascertain which of these interests should be considered "property" in determining basis under Section 1014 of the Internal Revenue Code which provides that:

[T] he basis of property in the hands of a person acquiring the property from a decedent or to whom the property passed from a decedent shall ... be the fair market value of the property at the date of the decedent's death. ${ }^{3}$

Property acquired or which has passed from a decedent is defined in part to be: [P]roperty acquired from the decedent by reason of death, form of ownership, or other conditions .... if by reason thereof the property is required to be included in determining the value of the decedent's gross estate. ... 4

Initially the reversion receives a "market value" basis under Section $1014^{5}$ while the life interest, passing by gift, receives a transferred basis under Section 1015(a). ${ }^{6}$ Since the reversioner receives a change in basis while the life beneficiary does not, three fundamental questions must be answered:" (1) To what extent, if any, is the trustee's basis affected by the settlor's death, (2) what is the legatee's basis for the reversion, and (3) what is the legatee's basis for the trust corpus upon its distribution at the life beneficiary's death.

${ }^{x}$ Although many of the same problems may be presented by either an interest for life or a period of years, the discussion which follows will be in terms of the life interest only. The comment will not deal explicitly with problems peculiar to depreciable property.

2 Consult 1 Bogert, Trusts and Trustees $\S 1$ (1951).

3 Int. Rev. Code $\$ 1014$ (a), 26 U.S.C.A. $\$ 1014$ (a) (1955).

4Int. Rev. Code $\$ 1014$ (b)(9), 26 U.S.C.A. § 1014(b)(9) (1955).

B Int. Rev. Code $\$ 1014,26$ U.S.C.A. $\$ 1014$ (1955). This is so because the reversion will be included in the estate and will pass to the legatee by bequest or inheritance. Consult Treas. Reg. 105, §81.13(a) (1955).

${ }^{6}$ Int. Rev. Code $\S 1015$ (a), 26 U.S.C.A. $\$ 1015$ (a) (1955). Of course if the settlor dies within three years of the transfer, and if the presumption that the transfer was in contemplation of death is not rebutted, the value of the entire property will be included in the estate. Int. Rev. Code $\$ 2035,26$ U.S.C.A. $\$ 2035$ (1955). The entire property will thus receive the "market value" basis. Int. Rev. Code $\$ 1014$ (b)(9), 26 U.S.C.A. $\$ 1014$ (b)(9) (1955); consult 1954 U.S. Code Cong. \& Adm. News 5065, 5066 (1955).

7 The questions can also arise on sale of a reversion at a price different from its basis. Consult text at 678 infra. The same is true of a gift of the reversion when its value is less than its basis. Consult Int. Rev. Code $\$ 1015$ (a), 26 U.S.C.A. \$ 1015(a) (1955). The significant factor is that the basis of the reversion (or remainder) is affected by a transfer in a manner different from that of the terminable interest. 
In answering these questions of interpretation the most desirable policy guides are clear: In order to prevent tax free receipt of capital gain no basis should be allowed that is not "paid for," either by investment ${ }^{8}$ or by receiving a Section 1014 basis through inclusion in an estate, and in order to prevent a tax on capital all basis for which such payment has been made should be allowed. Furthermore all persons acquiring property from a decedent should receive equal tax-basis treatment, regardless of the form of the transaction. ${ }^{9}$

The application of Section 1014 to the trustee's basis depends on whether the appreciated "property" included in the settlor's estate is regarded as the reversion or as the reversioner's actuarial share of the trust corpus. If "property" is interpreted to mean only the reversion, the basis of the trust corpus ${ }^{10}$ would be unaffected by the settlor's death. Suppose, for example, that the settlor transferred property to the trust having a basis and value of $\$ 100.00$ which had appreciated to a value of $\$ 150.00$ at his death, and that the reversioner's actuarial share of the trust property were 30 per cent, and the life beneficiary's 70 per cent. The literal reading of Section 1014 would continue the trustee's basis at $\$ 100.00$, even though the reversion had been included in the estate, and thereby received an increase of $\$ 15.00$ in its basis. ${ }^{11}$ Therefore if the trustee sold the trust property for $\$ 150.00$ a capital gains tax, falling ultimately on the legatee, ${ }^{12}$ would be payable on the full appreciation of $\$ 50.00^{13}$-notwithstanding the fact that $\$ 15.00$ of this appreciation already would have been "taxed" for the benefit of the legatee by being included in the settlor's estate. ${ }^{14}$ The result

${ }^{8}$ Investment here refers to basis acquired under Int. Rev. Code $\S 1012,26$ U.S.C.A. $\S 1012$ (1955) (cost basis). For the relationship between bases acquired under different provisions of the Code consult note 14 infra.

The policy of present law which refuses any increase in basis when property is exposed to the gift tax does not detract from the case for equal basis treatment of those who receive property which may obtain an increase in basis through exposure to the estate tax.

${ }^{10}$ The trustee would take a transferred basis equal to that of the settlor unless the market value of the property were less than its basis, in which case he would take a basis equal to the value. Int. Rev. Code $\$ 1015$ (a), 26 U.S.C.A. \$1015(a) (1955).

11 The settlor's basis of $\$ 30.00$ for the reversion would be increased under Section 1014 to $\$ 45.00$, which is the value of the reversion at the settlor's death, i.e., the reversion's 30 per cent actuarial share of the total property's value of $\$ 150.00$.

12. The tax will fall ultimately on the legatee either because of a diminished distribution from the trust on the life beneficiary's death resulting from the tax paid by the trustee, or because of a market discount of the value of the reversion on its sale resulting from the expectation of such a diminished distribution.

${ }^{13}$ Int. Rev. Code $\$ \$ 1001$ (a), (c), 1002, 26 U.S.C.A. $\$ \$ 1001$ (a), (c), 1002 (1955).

14 Int. Rev. Code $\S 1014,26$ U.S.C.A. § 1014 (1955) gives property received from a decedent a basis precisely as though it had been purchased by the legatee for its fair market value at the settlor's death. The inclusion of appreciated property in an estate thus has the same effect as though it had been sold, the basis being increased by payment of capital gains tax. Even though the policy of Section 1014 may be questioned, consult Vickrey, Agenda for Progressive Taxation, 139-40, 381, 396 (1947), basis received under it thus represents "investment" to the same extent as that received under Section 1012 (cost basis), Section 1013 (inventory value), or Section 1015 (transfer by gift or trust). 
of this double taxation ${ }^{15}$ would be to discourage sale of trust assets by the trustee. ${ }^{16}$

This could be prevented by regarding the "property" included in the settlor's estate as the reversioner's actuarial share of the trust corpus itself, thus increasing the trust basis by $\$ 15.00 .^{17}$ The fact that the trustee's basis is altered by the settlor's death, while the trustee's property interest is not otherwise affected, need not seem surprising. The trustee may be compared with the donee of a gift later held to be in contemplation of death. The donee, similar to the trustee, receives no additional property by virtue of the settlor's death, and yet receives a Section 1014 basis..$^{18}$ If the Section 1014 "property" is regarded as the reversioner's actuarial share of the trust corpus itself, then both the donee and the trustee come within the words of Section 1014(b)(9): "property acquired from the decedent by reason of ... other conditions ... is required to be included in determining the value of the decedent's gross estate. ..."19 The trustee, not only to prevent double taxation, but also to treat similarly all those acquiring property by bequest, should thus receive a Section 1014 increase in his basis.

It might be argued that because "property" equal only to $\$ 45.00$ was included in the settlor's estate only one $\$ 15.00$ basis increase should be allowed, and that this increase could be allowed to the reversioner or to the trustee, but not to both. The answer to this contention, however, is sufficiently supplied by the reasons for allowing both trustee and beneficiaries a basis at the time of the original transfer. ${ }^{20}$ Since the respective capital interests ${ }^{21}$ may be sold inde-

${ }^{15}$ The result in such a case can be thought of as either a double tax, with the property (reversion) being taxed once in the estate and once on sale by the trustee, or as a tax on capital, with the reversioner receiving a Section 1014 increase of $\$ 15.00$ in his capital investment which was taxed on sale of the trust corpus.

${ }^{16}$ This fact may also be seen by comparing the trust and reversion bases immediately before the life beneficiary's predicted death. If Section 1014 "property" is regarded as only the reversion, the trust basis will equal $\$ 100.00$. The reversion basis will, however, approach $\$ 115.00$ : the original Section 1014 basis of $\$ 45.00$ plus the $\$ 70.00$ allocable to the life interest. The rather incongruous result is that the reversioner would pay more tax if the trustee sold the corpus and distributed the proceeds than if the reversion or distributed trust assets were sold directly.

${ }^{17}$ No reason is seen why the theory suggested in the text above should not apply to a sale of the reversion as well as to the settlor's death. Thus either a sale of the reversion for $\$ 45.00$ or its inclusion in an estate at a value of $\$ 45.00$ would result in a trust basis of $\$ 115.00$. For the effect on the reversion-purchaser's basis of subsequent sale of trust assets by the trustee consult text at 678 infra.

${ }^{18}$ Consult note 6 supra.

${ }^{19}$ Int. Rev. Code $\$ 1014(\mathrm{~b})(9), 26$ U.S.C.A. $\$ 1014(\mathrm{~b})(9)$ (1955).

${ }^{20}$ The trustee would receive a basis of $\$ 100.00$ under Int. Rev. Code $\S 1015$ (a), 26 U.S.C.A. $\S 1015$ (a) (1955). The reversioner would receive a basis of $\$ 30.00$ and the life beneficiary one of $\$ 70.00$. The total utilizable basis would thus equal $\$ 200.00$.

${ }^{21}$ As implied by the allowance of basis, the reversion (or remainder) is regarded as a capital asset. Consult I. T. 3911, 1948 Cum. Bull. 66 (1948). The same is true under present law of the life interest. McAllister v. Commissioner, 157 F. 2d 235 (C.A. 2d, 1946). This latter fact, however, raises additional problems: Due to the "float" (consult note 25 infra), which increases the reversion basis and decreases the life-interest basis with the passage of time, a sale of the 
pendently the income from sale may be realized twice, and if a double basis were not allowed a tax on capital would result on sale of the interest to which basis was denied. ${ }^{22}$ Similarly, if Section 1014 increased only the reversioner's basis, a tax on capital would result from sale of appreciated trust corpus by the trustee. Just as the original investment of $\$ 100.00$ is represented by a total basis of $\$ 200.00$, so should the $\$ 15.00$ appreciated value taxed in the settlor's estate be represented by a total Section 1014 basis increase of $\$ 30.00$, allowing both the reversioner and trustee a $\$ 15.00$ increase in basis. ${ }^{23}$ In terms of the above hypothetical this would mean a trust basis of $\$ 115.00$ : the original settlor's basis of $\$ 100.00$, plus $\$ 15.00$, the amount of the Section 1014 increase due to inclusion of what is regarded as the reversioner's actuarial share of the trust corpus in the settlor's estate. The result is that no basis for which payment has been made is denied, and no basis for which payment has not been made is allowed. ${ }^{24}$

The answer to the second major problem-that of determining the legatee's basis for the reversion-is also unclear under present law. In the analogous life

life interest followed by sale of the reversion or untraded distributed trust assets would result in utilization of basis in excess of the original investment. While the basis of the reversion would continue to increase with the float, that of the purchased life interest would not be subject to a corresponding decrease. Consult Johnson N. Camden, 47 B.T.A. 926 (1942).

Alternatives are more easily suggested than recommended. To decrease the reversioner's basis by the amount of basis utilized by sale of the life interest would put the reversioner's basis at the caprice of the life beneficiary, whose interests might well conflict with those of the reversioner. To deny the life interest a basis on its sale would be to deny basis to what the McAllister court regarded as a capital asset. Neither alternative is clearly the better, but either is preferable to present law.

${ }^{22}$ If the trustee were denied a transferred basis he would pay capital gains tax on $\$ 100.00$ on sale of the trust corpus. At the maximum 25 per cent rate this would leave $\$ 75.00$ to distribute to the reversioner in place of the original $\$ 100.00$ capital investment. Such an impairment of capital without realization of capital loss is against sound tax law. Consult Doyle v. Mitchell Brothers Co., 247 U.S. 179 (1918). Similarly adverse results will occur on sale of the reversion itself with the capital tax then being represented by a market discount. Consult note 12 supra. If the settlor's basis were transferred to the trustee and denied to the reversioner or life beneficiary, impairment of the equitable interest holder's capital would result directly.

${ }^{23}$ A conceptualistic response can be made to this suggestion that additional investments should be represented by double basis: There is no further transfer to the trustee, so Section 1015(a) cannot operate to increase his basis. But this comment's theory would increase the trustee's basis under Section 1014-Section 1015(a) would not come into operation at all.

${ }^{24}$ If the value of the reversion at the settlor's death has fallen below its basis, consistency dictates that the trust basis be proportionately decreased. This follows from the fact that Section 1014 operates similarly to a capital loss realization, decreasing the reversioner's capital investment. If the trust basis were not decreased proportionately, the reversioner would receive a benefit, unwarranted by his decreased capital investment, from decreased capital gains taxes payable by the trustee on sale of the trust corpus. Assuming the market value of the trust corpus had fallen to $\$ 60.00$ at the settlor's death, the basis of the reversion would be decrease 1 from $\$ 30.00$ in the settlor's hands to $\$ 20.00$ in the legatee's hands. The reversion basis immediately before the life beneficiary's predicted death would thus equal $\$ 90.00$ : the original Section 1014 basis of $\$ 20.00$ plus the $\$ 70.00$ "float" from the life interest. Consult text at 676 infra. The reversioner would thus pay less tax if the trustee sold the corpus and distributed the proceeds than if the reversion were sold directly. The same discussion applies to sale of a reversion at a price less than its basis (consult note 17 supra), or to a gift when the value is less than basis. 
estate-remainder situation the basis of the remainder is increased or "floated," and that of the life interest decreased until, at the life beneficiary's death, the entire basis allocable to the life interest at the time of the original transfer is shifted to the remainderman. ${ }^{25}$ This is done so that upon a subsequent sale the remainderman will incur no tax liability due solely to lapse of time. No loss of basis results from the existence of the terminable interest. ${ }^{26}$

No reason appears why the same procedure should not be used to determine the reversioner's basis. If this rule were applied to the present problem, the basis of the legatee's reversion would increase as the basis of the life interest decreased, until at the life beneficiary's death it would equal the sum of its original Section 1014 basis $(\$ 45.00)$, plus the basis allocable to the life interest at the settlor's death $(\$ 70.00)$, or a total of $\$ 115.00$. Since under constant market conditions the value and basis of the reversion will increase in the same ratio, on sale of the reversion or of the distributed trust assets no gain will be recognized due solely to lapse of time.

Another factor, receiving no recognition under present law, which might affect the basis of the reversion is a sale of the trust corpus by the trustee. If

${ }^{25}$ The basis of the life interest is determined by multiplying the present value of one dollar payable at the end of each year for the rest of the life beneficiary's life, by the amount of the annual yield of the property computed at a return of $3 \frac{1}{2}$ per cent on the value of the fee as of the decedent's death. Treas. Reg. 118, $\$ 39.113(\mathrm{a})(5)-1$ (f) (1955); Treas. Reg. 105, $\$ 81.10(\mathrm{i})(5)$ (1956); I.T. 2076, III-2 Cum. Bull. 18 (1924) (example of basic rule); I.T. 3911, 1948 Cum. Bull. 66 (1948) (providing for adjustment of basis to date of sale). Since in a testamentary situation the uniform basis (total basis of the underlying property) equals the value of the property at the decedent's death, the result of the above computation (assuming no other adjustment to basis under Section 1016) will give the basis of the life interest at the date of sale. Where the basis of the underlying property does not equal its value the computation should be made with reference to basis, or if computed with reference to value, adjusted by the formula:

$\frac{\text { Basis of life interest at time of sale (unknown) }}{\text { basis of total property at time of sale }}=\frac{\text { value of life interest at time of sale }}{\text { value of total property at time of sale }}$

The basis of the remainder is obtained by multiplying the figure appearing in the second column of Table I of Treas. Reg. 105, $\$ 81.10(\mathrm{i})(5)$ opposite the age of the life beneficiary times the basis of the underlying property. I.T. 3911, 1948 Cum. Bull. 66 (1948).

${ }^{26}$ This is true either of a sale of the remainder interest, note 25 supra, or of a sale of the distributed trust assets on termination of the life interest. An example of the latter is William $H$. Slack, Jr., 36 B.T.A. 105, 107 (1937) where it was said that "[t]he vendor was not selling a remainder interest. . . . [a]pplying the words of the statute, real property was sold which was acquired by specific devise. [After the remainderman came into possession] ... the fact that there had been an intervening life estate, had become an academic consideration. . . " Furthermore, the regulations provide that "[t]he purpose of the Internal Revenue Code, in prescribing a general uniform basis rule [allowing the remainderman the basis of the entire underlying property determined at the life beneficiary's death] for property acquired by bequest, devise, or inheritance, is ... not to recognize as gain any element of value solely from the circumstance that the possession or enjoyment of the taxpayer was postponed. Such postponement may be ... until the period of the possession or enjoyment of another has terminated. ..." Treas. Reg. 118, \$39.113(a)(5)-1(b)(1) (1955). Consult Fidelity \& Columbia Trust Co. v. Commissioner, 90 F. 2d 219 (C.A. 6th, 1937), cert. denied 302 U.S. 723 (1937); Huggett v. Burnet, 64 F. $2 d 705$ (App. D.C., 1933). 
the theory suggested earlier in this comment ${ }^{27}$ were consistently applied, any increase in the trust basis resulting from payment of capital gains tax on sale of appreciated trust corpus would be reflected in the basis of the reversion on its sale by the legatee. The basis benefit resulting from payment of such a tax by the trustee should inure to the reversioner for the same reasons that including the reversion in the settlor's estate should increase the trust basis: tax paid by the trustee is in effect a tax paid by those eventually to receive the corpus.

In addition it should be noted that the legatee-reversioner, like a remainderman under present law, presumably would receive the trustee's basis upon distribution of any trust assets that had been traded by the trustee. ${ }^{28}$ Hence, if the basis of the reversion is not increased proportionately with any increase in the trust basis, a sharp increase in the legatee's basis will result at the life beneficiary's death. Thus even though the trustee in the above hypothetical had traded appreciated trust corpus until it had a basis of $\$ 200.00$, present "float" theory presumably would allow the basis of the reversion to approach only $\$ 115.00$ immediately before the life beneficiary's predicted death. This discrepancy between the basis of the reversion and that of the trust corpus and distributed trust assets unnecessarily discourages sale of the reversion by subjecting the legatee-reversioner to greater tax on its sale than would be paid either on sale of the distributed trust assets or of the trust corpus. ${ }^{29}$

A better solution would be to compute the basis of the reversion with reference to that of the trust corpus, thus allowing the legatee-reversioner the benefit of any increase in the trust basis resulting from realization of capital gain by the trustee.

In the absence of trading by the trustee the reversion basis may be thought of as the sum of the Section 1014 change resulting from including the "property" in the settlor's estate plus the reversioner's actuarial share of the settlor's original basis. This basis $(X)$ may be expressed as:

where:

$$
X=I+M(S)
$$

$I$ equals the Section 1014 change.

$M$ equals the reversioner's actuarial share of the total property at any point in time. $S$ equals the settlor's original basis.

Suppose that the trustee then effected a trust basis increase through realization of an amount of appreciation not in excess of that which had occurred before the settlor's death, and that thereafter the reversion were sold. Since his actuarial share of the total property has increased with the passage of time, the reversioner should be allowed to benefit from the trustee's realization of this "pre-death"

${ }^{27}$ Consult text at 674 supra.

${ }^{28}$ Maguire v. Commissioner, 313 U.S. 1 (1941); Helvering v. Reynolds, 313 U.S. 428 (1941). These cases establish the general rule that remaindermen of testamentary trusts take the trust basis for traded assets. No reason is seen why the same rule should not apply to reversioners.

28 Compare note 16 supra. 
appreciation..$^{30}$ In order to prevent a double benefit from the same increment of appreciation, the Section 1014 basis increase already allowed to both the trust and reversion bases must be taken into account. This is done by allocating the trust basis increase attributable to realization of "pre-death" appreciation over the period of time from the settlor's death to the predicted death of the life beneficiary. The proper share of this increase allocable to the reversion is:

where:

$$
\frac{L}{L+E}(T)
$$

$L$ equals the number of years since the settlor's death.

$E$ equals the life beneficiary's life expectancy as of the date basis is determined.

$T$ equals trust basis changes attributable to the "pre-death" increment of value, and which result from trading by the trustee. ${ }^{31}$

The reversion basis also should reflect the reversioner's direct actuarial share of any trust basis changes attributable to any increment of value above the market value of the property at the settlor's death. Where these "post-death" increases or decreases are represented by $A$ the reversion basis finally may be expressed as:

$$
X=I^{32}+M(S+A)+\frac{L}{L+E}(T)^{33}
$$

Parallel problems must be faced in determining the basis of a purchased reversion. Under present law this basis would be cost. ${ }^{34}$ Thus upon distribution

${ }^{30}$ In terms of the hypothetical the "pre-death" appreciation could not exceed $\$ 50.00$. If the value of the property fell to $\$ 120.00$ after the settlor's death, and later rose to $\$ 140.00$ when the property was sold, a "pre-death" appreciation of $\$ 40.00$ would have occurred.

${ }^{31}$ The $T$ factor is bounded by the value of the property at the settlor's death and the trustee's "death" basis, and will reflect gains or losses occurring only within this area. In terms of the hypothetical the $T$ factor equals the $\$ 35.00$ lying between the trustee's "death" basis of $\$ 115.00$ and the market value of $\$ 150.00$.

${ }^{32}$ Since Section 1014 gives the " $T$ " increase directly to both the trust and reversion bases, difficulty may be encountered in creating a symmetrical capital loss treatment. For example if the hypothetical trust basis goes to zero, presence of the $I$ factor in the formula would give a reversion basis of $\$ 15.00$. Consistency with the present policy of restricting the benefit from capital losses would reduce the basis of the reversion directly with the trust basis decrease that corresponded with its Section 1014 increase. In the hypothetical the reversioner's basis would be decreased directly if the trustee sold the property between $\$ 115.00$ and $\$ 100.00$. Once the $I$ factor has been completely removed from both the reversion and trust bases by a trustee's realization at a price of $\$ 100.00$, future computation could be done in a direct actuarial manner: the $L /(L+E)$ allocation of the $T$ factor no longer would be required.

${ }^{33}$ In terms of the hypothetical these factors may be thought of as increments on a continuum bounded as follows: $S$ from 0 to $\$ 100.00 ; I$ from $\$ 100.00$ to $\$ 115.00 ; T$ from $\$ 115.00$ to $\$ 150.00$; and $A$ from $\$ 150.00$. Changes in the trust basis attributable to changes in value within these increments are properly translated into changes in the basis of the reversion by respective substitution into the formula, with the exception that losses occurring over the $S$ increment should be substituted into the $A$ factor.

${ }^{34}$ Int. Rev. Code $\S 1012$, 26 U.S.C.A. $\$ 1012$ (1955). 
of trust assets which had been traded by the trustee the purchaser presumably would not receive the trustee's basis, nor would the reversion benefit from any "float" from the life interest or from any trading by the trustee. But the reversion-purchaser-alter ego of the truste ${ }^{35}$ - -in effect pays for the increased trust basis by his eventual receipt of diminished distribution of trust corpus resulting from payment of capital gains taxes by the trustee. "Cost" increases in the basis of the trustee thus should yield "cost" increases in the basis of the reversionpurchaser. Present law may be applied by analogy: Maguire v. Commissioner ${ }^{36}$ held that a legatee-remainderman would take the trust basis on distribution of trust assets that had been traded by the testamentary trustee. Since the Maguire beneficiary acquired his right to receive the trust property by bequest, it cannot be argued that he received the trustee's basis for the traded assets by virtue of the transferred basis provisions of the Code, which are applicable only to transfers by gift. ${ }^{37}$ There is thus a persuasive analogy from the Maguire case to that of a purchased reversion: Since the Court properly allowed the remainderman the benefit of increases in the trust basis where literal application of the Code would have prescribed a death basis, ${ }^{38}$ it should allow this benefit where literal application of the Code would prescribe a cost (of the reversion) basis. If a legatee-remainderman is allowed the increases in trust basis to protect what is in reality his own investment, so should a purchaser of a reversion.

This interpretation of the Maguire case allows the reversion-purchaser a basis for the distributed trust assets equal to his cost for the reversion plus any increase in the trust basis due to trading by the trustee. Since this theory allows the trustee to pass this benefit to the reversion-purchaser, there will be no unnecessary restraint on the trading of trust assets. ${ }^{39}$

Once the reversion-purchaser is allowed the benefit of increases in the trust basis on distribution of traded trust assets he should also be allowed a proportionate share of that increase on resale of the reversion. The earlier argument justifying this point as to the legatee-reversioner ${ }^{40}$ applies here with equal

${ }^{35}$ The trustee and beneficiaries are so related in many respects as not to be separate entities. For example, in Maguire v. Commissioner, 313 U.S. 1, 7 (1941) where, in determining the "time of acquisition" under Section 113(a)(5) of the 1939 Code (the predecessor of Section 1014), it was said that " '[d]istribution to the taxpayer' is not necessarily restricted to situations where property is delivered to the taxpayer. It also aptly describes the case where property is delivered by the executors to trustees in trust for the taxpayer."

${ }^{36} 313$ U.S. 1 (1941). $\quad{ }^{37}$ Int. Rev. Code § 1015(a), 26 U.S.C.A. § 1015(a) (1955).

${ }^{38}$ The remainderman acquired the property by bequest. Because if it is true as said in Shelby H. Curlee, 28 B.T.A. 773, at 778 (1933) that "[a] gift effected by a transfer in trust is none the less a gift," then it must be true that a bequest effected by a testamentary trust is nonetheless a bequest. Therefore a literal application of Section 113(a)(5) of the 1939 Code (the predecessor of Section 1014) would prescribe a death basis.

39 The trustee's ability to pass his basis increases to the reversioner coupled with allowing the trustee an increased basis on sale or inclusion in an estate of an appreciated reversion (consult note 17 supra) completely frees the reversioner from economic penalty on trading of the trust assets.

${ }^{10}$ Consult text at 677 supra. 
force. The only difference between the basis of the legatee's reversion in the above hypothetical and that of a purchaser from the settlor for $\$ 45.00$ would be that the purchaser's basis would not reflect any "float" of basis from the life interest. ${ }^{41}$ The reversion-purchaser's precise actuarial share of the total basis for which payment has been made could be determined at any time by using a variation of the earlier formula:

where:

$$
X=I+K+M(A)+\frac{L}{L+E}(T)
$$

$I$ equals trust and reversion basis changes resulting from the sale of the reversion. $K$ equals the basis of the reversion in the hands of the settlor.

$M$ equals the reversion-purchaser's actuarial share of the total property at any point in time.

$A$ equals trust basis changes attributable to the "post-sale"42 increment of value.

$L$ equals the number of years since the sale of the reversion.

$E$ equals the life beneficiary's life expectancy as of the date basis is determined.

$T$ equals trust basis changes attributable to the "pre-sale" increment of value, and which result from trading by the trustee.

The legatee-reversioner's basis for distributed trust assets that have not been traded by the trustee could equal the value at the settlor's death of either the reversion or the trust corpus, depending on the meaning of "property" as used in Section 1014. Present law presumably allows a basis equal to the value of the trust corpus. ${ }^{43}$ Section 1014 defines property which is accorded a death basis as "property in the hands of a person acquiring the property from a decedent [settlor]. . . ."44 [Italics added.] Upon termination of the trust the only "property" in the hands of the legatee-reversioner which was acquired from the settlor [decedent] is the trust assets. Thus a literal reading of Section 1014 favors determining the basis of untraded distributed trust assets by their value at the date of the settlor's death. ${ }^{45}$

In terms of the original hypothetical this would result in giving the legateereversioner a basis of $\$ 150.00$ for the distributed trust assets even though these assets had a basis of only $\$ 115.00$ in the trustee's hands, and the basis of the reversion approached only $\$ 115.00$ immediately before the life beneficiary's

${ }^{41}$ The "float" to a reversion-purchaser would be a clear violation of the cost basis principle and should not be allowed.

42 The "pre-sale" and "post-sale" concepts are analogous to the "pre-death" and "postdeath" concepts explained supra at note 30 and page 678 . The similarity between the two formulas is evident, and much of the prior discussion will apply here.

433 Mertens, Law of Federal Income Taxation $\$ 21.61$ (1942); cf. Helvering v. Reynolds, 313 U.S. 428 (1941) (life estate and remainder both passing through the estate). Consult note 26 supra.

14 Int. Rev. Code § 1014(a), 26 U.S.C.A. § 1014(a) (1955).

${ }^{45}$ Unpublished rulings have been made to this effect where the reversion, but not the life interest, was included in the estate. Letter from attorney of Internal Revenue Service dated June 7, 1956. 
predicted death. There would never by any "payment" for this $\$ 35.00$ basis increase because the appreciation allocable to the outstanding life interest was included in that "property" used to defined the Section 1014 basis of the distributed trust assets, but was not included in the settlor's estate..$^{46}$

Apparently the words of Section 1014 were written without contemplation of this specific problem since the principle of awarding only "paid for" basis"7 - with which Section 1014 generally is consistent ${ }^{48}$-requires a different application of the word "property." In determining the legatee's proper basis for the distributed trust assets it should be remembered that if the settlor had survived the life beneficiary his basis for the distributed trust assets would have been $\$ 100.00 .6^{49}$ The legatee's basis should not be less than that in the absence of diminution in value of the property, and should include so much of the appreciation as was included in the estate. Since in the hypothetical $\$ 15.00$ was so included, a proper allowance of basis would be $\$ 115.00$. Then if the legateereversioner sold the distributed trust assets for $\$ 150.00$ the entire $\$ 50.00$ appreciation would be taxed: $\$ 15.00$ in the settlor's estate, ${ }^{50}$ and $\$ 35.00$ on the subsequent sale.

Since the principles applied to gains apply similarly to losses, if at the settlor's death the value of the property has fallen below its basis, the legatee's basis should reflect so much of the diminution as was "included" in the estate. Thus if the value had fallen to $\$ 50.00$, proper basis for the untraded distributed trust assets would be $\$ 85.00 .^{51}$ If the legatee-reversioner sells these assets for $\$ 50.00$, the entire diminution in value would be accounted for: $\$ 15.00$ "loss" by inclusion of the reversioner's actuarial share of the diminution in the settlor's estate, ${ }^{52}$ and $\$ 3500$ capital loss on the sale.

${ }^{45}$ Appreciation allocable to the life interest properly may be used to define Section 1014 basis where both interests are included in the estate. For example, in Helvering v. Reynolds, 313 U.S. 428 (1941) a testamentary trust was created to pay income to A for life with remainder to $B$. The Court held that the remainderman would take the value of the trust corpus at the settlor's death as his basis for untraded distributed trust assets. Since the basis allowed to the remainderman exactly equalled the value of the property included in the estate, the amount of basis allowed is precisely that for which "payment" has been made.

17 Consult text at 673 supra.

18 Ordinarily property cannot receive a Section 1014 basis without being exposed to the estate tax by being included in the decedent's gross estate under Int. Rev. Code $\$ 2031$, 26 U.S.C.A. $\S 2031$ (1955). Certain property is given the Section 1014 basis without being included in the estate, consult Int. Rev. Code $\S 1014(\mathrm{~b})(6-8), 26$ U.S.C.A. $\$ 1014$ (b)(6-8) (1955), but none of those exceptions applies to the problem under discussion.

19 The trustee would take the settlor's original $\$ 100.00$ basis under Int. Rev. Code $\$ 1015$ (a), 26 U.S.C.A. \$1015(a) (1955) and would transfer it back on the life beneficiary's death. Cf. Helvering v. Reynolds, 313 U.S. 428 (1941).

so "Taxed" is here used synonymously with "included" insofar as Section 1014 is concerned.

${ }^{31}$ This $\$ 85.00$ is determined by subtracting the reversioner's actuarial share ( 30 per cent) of the value diminution of $\$ 50.00$ from the settlor's original $\$ 100.00$ basis. It can be thought of alternatively as the reversion's Section 1014 basis of $\$ 15.00$ plus the "float" of $\$ 70.00$ from the life interest.

52 Consult note 24 supra. 
The basis problems resulting from the death of a reversioner-settlor of an inter vivos trust highlight the present uneasy state of applicable law. Two principles, however, are clear: All taxpayers acquiring property from a decedent should receive equal basis treatment; and basis should be allowed only if, and to the extent that it has been "paid for" within the framework of the Code.

While the recommendations of this comment reflect the inherent complexity of the problem, they amount essentially to this: In determining proper basis, and hence tax liability, the various outstanding property interests created by use of the trust form should receive the benefit of any taxable events which initially affect any one of these related interests. Treating these interests separately, as would apparently be done upon mechanical application of present statutory provisions, is unnecessary as well as inequitable.

\section{PROXY CONTESTS: CORPORATE REIMBURSEMENT OF INSURGENTS' EXPENSES}

Until recently, no court had considered the questions of whether and to what extent corporate funds properly may be employed to defray the expenses of proxy solicitations incurred either by successful or unsuccessful insurgent shareholders in contests for control of the board of directors. ${ }^{1}$ No reported decision yet appears concerning unsuccessful insurgents, and only two have dealt at any length with successful insurgents. ${ }^{2}$ These indicate that where insurgent share-

1 Other discussions of insurgents' proxy expenses are found in Emerson and Latcham, Shareholder Democracy, c. 6 (1954), and a series of articles by these authors: Proxy Contests: Competition for Management Through Proxy Solicitation, 8 So. West. L.J. 403 (1954); Proxy Contest Expenses and Shareholder Democracy, 4 West. Res. L. Rev. 5 (1952); Proxy Contests: A Study in Shareholder Sovereignty, 41 Calif. L. Rev. 393 (1953). Consult also Friedman, Expenses of Corporate Proxy Contests, 51 Col. L. Rev. 951 (1951); Financing Proxy Contests With Corporate Funds, 44 Geo. L.J. 303 (1956); Expenses of a Proxy FightThe Problem of Reimbursement by the Corporation, 10 So. West. I.J. 44 (1956); Corporations: Reimbursement for Corporate Campaign Expenses Incurred in Proxy Fights, 43 Calif. L. Rev. 893 (1955); 7 West. Res. L. Rev. 198 (1956), noting Rosenfeld v. Fairchild Engine \& Airplane Corp., 309 N.Y. 168, 128 N.E. 2d 291 (1955); and 61 Yale L.J. 229 (1952), 36 Cornell L.Q. 558 (1951), noting Steinberg v. Adams, 90 F. Supp. 604 (S.D. N.Y., 1950).

For a discussion of various other issues which evoke solicitations by opposition groups consult the following articles by Emerson and Latcham: Proxy Contests: Competition for Management Through Proxy Solicitation, 8 So. West. L.J. 403 (1954); 41 Calif. L. Rev. 393 (1953); The SEC Proxy Proposal Rule: The Corporate Gadfly, 19 U. of Chi. L. Rev. 807 (1952).

2 Only three reported cases have dealt with the problem. Rosenfeld v. Fairchild Engine \& Airplane Corp., 309 N.Y. 168, 128 N.E. 2d 291 (1955); Cullom v. Simmonds, 285 App. Div. 1051, 139 N.Y.S. 2d 401 (2d Dep't, 1955); Steinberg v. Adams, 90 F. Supp. 604 (S.D. N.Y., 1950) (applying Delaware law).

Some reasons may be advanced for the lack of cases: (1) the infrequency of successful insurgencies; (2) the seeming finality of shareholder ratification; (3) the apathy of most shareholders; and (4) the risk of paying the entire cost of litigation if unsuccessful in "making law" on this subject. Traditionally the "outs" have borne the cost of their failure, and it has apparently not occurred to them that there may be a basis for claiming reimbursement. 